\title{
急硬性セメントの研究
}

\author{
露 木 尚 光・笠 井 順 一
}

（日本大学理工学部）（日本大学生産工学部）

\section{Study on Rapid Hardening Cement}

By

\author{
Naomitsu TSUYUKI* and Junichi KASAI**
}

* Department of Chemistry, Faculty of Science and Engineering, Nihon University,
Funabashi, Chiba, Japan.
** Department of Industrial Chemistry, Faculty of Industrial Technology, Nihon
University, Narashino, Chiba, Japan.

The object of the present study is to prepare the cement suitable for particularly urgent construction work. This is "blended cement" consisting of aluminous cement-lime system. Our experiment showed that setting time could be controlled by using some kind of setting retarder. We found the suitable proportion of the mixture and the most effective setting retarder. In this paper, we dealt with the blended cements that set during from several ten seconds to a few minutes, and developed high compressive strength.

The results are summarized as follows:

(1) When lime is added to aluminous cement, it comes to flash setting which makes the cement useless practically.

(2) Under the condition of high alkalinity, the setting time can be retarded when about $1 \%$ of the setting retarder that formed coordination compounds with $\mathrm{Ca}^{2+}$ is added into the cement. The most effective setting retarder is $\mathrm{Ca}-2$ keto gluconate.

(3) Composition of the mixture to develop desirable high compressive strength is as follows ;

aluminous cement, $100 \mathrm{~g}$ and $\mathrm{Ca}(\mathrm{OH})_{2}, 20 \mathrm{~g}$, or dolomite plaster, $25 \mathrm{~g}$. Water cement ratio is $35 \%$.

(4) Setting time can be also a little retarded by means of addition of portland cement or $\mathrm{CaSO}_{4} \cdot 2 \mathrm{H}_{2} \mathrm{O}$ to aluminous cement-lime system.

In addition to this experiment, we discussed the mechanism of hydration and hardening reaction on the basis of the results on X-ray diffraction and differential thermal analysis.

[Received April 3, 1969]

\section{1. 緒言}

最近非常に凝結硬化の速いセメントが必要とされるよ らになった。今までのセメントのように 1 時間〜数時間 で凝結, 硬化するセメントと異なり, 数十秒〜数分で硬 化するセメントも, 今後相当に重要視されるものと思わ れる。すでにアメリカでは Fast Fix Cement や Jet Set などの商品名で市販されている。

たとえば，七メント・モルタルの吹き付けをする土木 T、事に掠いて，ノズルの先で水上瞬間的に混合し吹き付 けるよ5な場合には, 数秒〜30 秒程度で凝結, 硬化寸 るセメントがよい. 地下鉄工事の漏水止めなどの緊急工 事用には，30 秒〜 2 分程度で凝結，硬化するもの，ま たセメント 2 次製品などの補修用としては, 数分〜20 分 程度で㠜結，硬化するセメントが望ましい'，もしも価 格が安くなれば，モールド用石高に代るモールド用セメ
ントとして，この方面での用途，市場の開発もできるで あろら。

本研究はアルミナ・セメントに石灰類を加え, これに 凝結遅緩剂として有機化合物を添加することによって, 水和反応を抑制し, 凝結を遅緩させて前に述べた目的の セメントを試作した. すなわち，アルミナ・セメント， 石灰類および有機化合物を基材とした急硬性セメントで ある。

普通ポルトランド・セメントは, 凝結始発から終結ま での時間が長い。これに対して，本研究で扱ったセメン トの特徵は, 凝結始発まではセメント・ペーストの粘度 をほとんど変化させないで，始発になるとただちに終結 に達し，同時に硬化してしまうことである.

著者らはつぎに述べる実験方法に基づいて，実験室的 に試作したこれらセメントの化学成分と凝結時間, 圧縮 
強度などの諸性質との関係, および添加剤の問題を解析 した.この報告は, 10 秒 数分程度で凝結, 硬化する セメントを主たる対象とした. したがって，数分〜20 分程度で硬化するものについては別に報告する。

\section{1 基礎的な考え方}

\section{2. 実 験 方 法}

アルミナ・セメント（以下 A.C. と略記する）に石灰 類またはポルトランド・セメント（以下 P.C. と略記す る）を加えると瞬結性となり ${ }^{2)}$ ，セメントとしては使用 しがたい、しかしアルカリ性の条件下で $\mathrm{Ca}^{2+}$ をイオン 封鎖するような物質を添加すると，水和反応を抑制し， 凝結時間を数十秒〜数分の程度に長くすることが可能で ある ${ }^{3)}$ 。この時間は, 添加物によって相当にちがう. 著 者らはこの考え方に基づいて, A.C.一石灰類一P.C.$\mathrm{Ca}^{2+}$ 封鎖剤系を中心に検討した.

\section{2 供試セメントの調整と水和条件}

アルミナ・セメント $100 \mathrm{~g}$ に消石灰あるいはドロマイ ト・プラスター（以下 D.P. と略記する）を種々の割 合 $(0,5,10,15,20,25,30 \cdots \mathrm{g})$ で加え, その全量 100 部にイオン封鎖剤 (表-2 参照) を一部添加し, 充 分均一に混合して, 水セメント比 $35 \%$ で水和させた. これより高強度が期待できる配合比を明らかにして, 緒 言に述べた目的の急硬性セメントを実験室的に試作し た.

\section{3 実験試料}

本報で取上げた急硬性セメントの原料として用いる市 販のアルミナ・セメントは, 品種により相当に異なった 結果を示すが, ポルトランド・セメントや石灰類では品 種の影響は少ない．ここで用いる石灰類は消石灰とドロ マイト・プラスターである・なお本研究に用いたアルミ ナ・セメントは, 電化アルミナ・セメント 1 号（=電化 1 号. 電気化学工業 (株) の製品) である.このセメン トの化学組成および一般物理性を表-1 に示した。消石

Table 1. Physical and chemical properties of DENKA aluminous cement No. 1 .

1) Chemical compositions (wt\%)

\begin{tabular}{ccccccc}
\hline $\mathrm{Al}_{2} \mathrm{O}_{3}$ & $\mathrm{CaO}$ & $\mathrm{SiO}_{2}$ & $\mathrm{Fe}_{2} \mathrm{O}_{3}$ & $\mathrm{TiO}_{2}$ & $\mathrm{MgO}$ & Total \\
54.4 & 38.0 & 4.2 & 1.0 & 2.3 & 0.1 & 100.0 \\
\hline
\end{tabular}

2) Physical properties (according to JIS R 2521)

\begin{tabular}{|c|c|c|}
\hline (1) & Fineness & 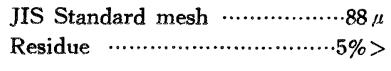 \\
\hline (2) & Setting time & 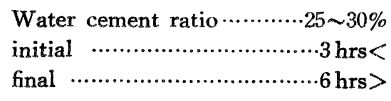 \\
\hline (3) & $\begin{array}{l}\text { Compressive } \\
\text { strength }\end{array}$ & 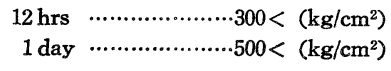 \\
\hline (4) & Bending strength & 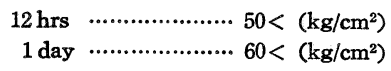 \\
\hline (5) & Refractoriness & $1435^{\circ} \mathrm{C}<$ \\
\hline
\end{tabular}

灰はのちに述べる解析のために消石灰試薬 1 級を用い た. ドロマイト・プラスターは日本プラスター(株)の市 販上塗り用である。またポルトランド・セメントとして は，小野田セメント (株) 製の普通ポルトランド・セメ ントを使用した。

\subsection{A.C. 一石灰類系}

\section{3. 実 験 結 果}

この系では瞬結性となり，いわゆるセメントとしての 作用は期待できない.アルミナ・セメント $100 \mathrm{~g}$ に対し て石灰類としてたとえば消石灰を加えていくと，わずか $0.5 \%$ でも急結になる (図-4 参照).この場合は消石灰 の量や水量で凝結時間を調整するのは困難である. 著者 らは 2.2 による試料調整方法と水和条件に基づて, 30 分後の圧縮強度を測定した. この場合の $\mathrm{Ca}^{2+}$ 封鎖 剤として, 2 ケトグルコン酸カルシウム ${ }^{4), 5)}$ (以下 $\mathrm{Ca} \cdot 2$ K.G. と略記する）を用いた. 実験結果を図-1 に示し た.

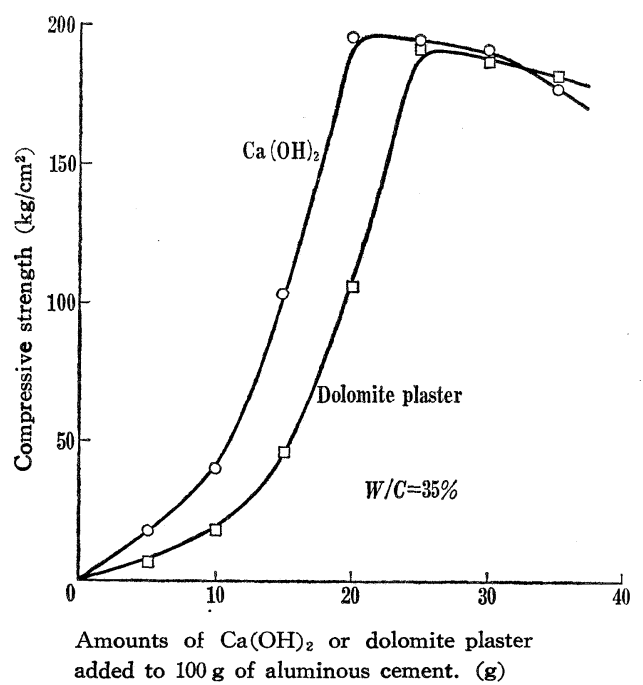

Fig. 1. Relations between the amounts of $\mathrm{Ca}(\mathrm{OH})_{2}$ or dolomite plaster added to $100 \mathrm{~g}$ of aluminous cement and compressive strength after 30 minute curing.

\section{2 イオン封鎖瓯}

図-1 より最高強度が期待できる配合比が 判明した。 すなわち，

(1) A.C. $=100 \mathrm{~g}$

(2) $\mathrm{Ca}(\mathrm{OH})_{2}=20 \mathrm{~g}$ または D.P. $=25 \mathrm{~g}$

(3) イオン封鎖剤 $=(1)+(2)$ の $1 \%$

（4）水セメント比 $=35 \%$

上記の配合比に調整して凝結時間および 30 分後の圧 縮強度を測定した. 石灰類としてドロマイト・プラスタ 一を用いて各種のイオン封鎖剤を検索した。実駼結果を 表-2 に示した。 
Table 2. Hydraulic properties of blended systems consisting of aluminous cement, dolomite plaster, and setting retarder.

\begin{tabular}{|c|c|c|c|}
\hline & Setting retarder $(1 \%)$ & $\begin{array}{l}\text { Final setting } \\
\text { time } \\
\text { min. sec. }\end{array}$ & $\begin{array}{l}\text { Compressive } \\
\text { strength after } 30 \\
\text { minute curing } \\
\left(\mathrm{kg} / \mathrm{cm}^{2}\right)\end{array}$ \\
\hline (1) & Milk casein & $0^{\prime} \quad 45^{\prime \prime}$ & 91.3 \\
\hline (2) & Sodium tripoly phosphate & $\longrightarrow$ & - \\
\hline (3) & Sodium citrate & $0^{\prime} \quad 50^{\prime \prime}$ & 98.3 \\
\hline (4) & Aluminium phosphate & - & - \\
\hline (5) & 1 Sodium hydro phosphate & - & - \\
\hline (6) & Ammonium oxalate & - & - \\
\hline (7) & E.D.T.A. & $0^{\prime} \quad 48^{\prime \prime}$ & 146.5 \\
\hline (8) & Calsium gluconate & $03^{\prime \prime}$ & 112.5 \\
\hline (9) & Calsium 2-keto gluconate & $2^{\prime} \quad 03^{\prime \prime}$ & $197.5 \sim 210.0$ \\
\hline (10) & Calsium 5-keto gluconate & - & - \\
\hline (11) & Gum arabic & - & - \\
\hline (12) & Starch & - & - \\
\hline (13) & Gloiopeltis & - & - \\
\hline
\end{tabular}

(- - : flash setting)

この実験結果によると,グルコン酸カルシウム， 2 ケ トグルコン酸カルシウムなどの塩類が，比較的この試作 セメントの凝結遅緩に有効であった。個々のイオン封鎖 鼡が示す遅緩効果を具体的に記すと，つぎのようにな る.

ミルクカゼインは難溶性で，その溶解度は僅か 0.11 $\mathrm{g} / l$ 程度であり，効果が少ない。ただし，のちに述べる A.C.一石灰類一P.C. 系では効果がある.

トリポリ燐酸ナトリウムは中性の条件でイオンを封鎖 できるが，アルカリ性では $\mathrm{Ca}^{2+}$ 封鎖剤にはならない。 したがって, あらかじめ予想したよらに効果はなかっ た.

クエン酸ナトリウムは $\mathrm{Al}^{3++}$ 封鎖剤として効果が知ら れているが，また $\mathrm{Ca}^{2+}$ のイオン封鎖剤ともなる ${ }^{5}$ 。し たがって，凝結遅緩効果がある。

葆酸アンモニウムは $\mathrm{Al}^{3+}$ の封鎖に効果があるが， $\mathrm{Ca}^{2+}$ のイオン封鎖剂とはならないので効果がない.

この実験により，A.C.一石灰類系の添加剤は $\mathrm{Ca}^{2+}$ 封 鎖剤でなくてはならないことが理解できる.

E.D.T.A. は $\mathrm{pH}=10$ 程度で封鎖能力が大きいが, この試作セメントのように強アルカリ性 $(\mathrm{pH}=12.0$ 13.0 程度) では効果が少ない。 またグルコン酸塩, 2 ケトグルコン酸塩は強アルカリ性の条件下でイオン封鎖 能力があるために，凝結遅緩効果が大きい，その他，フ ノリ，殿粉，アラビアゴムを使用してみたが効果は認め られなかった。

3.3 A.C. - 石灰類一P.C. 系

前記の A.C.一石灰類系にさらに普通ポルトランド・ セメント・クリンカーを加えた．このクリンカーは小野 田セメント（株）の製品で，粉末度はブレーン法で約 $3,000 \mathrm{~cm}^{2} / \mathrm{g}$ 程度に微粉砕したものを使用した.

その結果,

(1) A.C.一石灰類一P.C. クリンカー系は瞬結性で
ある。

（2）A.C.一石灰類一P.C. 系はある程度凝結が遅緩 される。

したがって，(1) と（2）より，凝結が遅緩される原因 は，ポルトランド・セメント中に含まれる $\mathrm{CaSO}_{4} \cdot 2$ $\mathrm{H}_{2} \mathrm{O}^{6}$ に起因していることが判明した。すなわち，A.C． 一石灰類系に $\mathrm{CaSO}_{4} \cdot 2 \mathrm{H}_{2} \mathrm{O}$ やポルトランド・セメント を加えることによって，凝結を遅緩させることができ る.

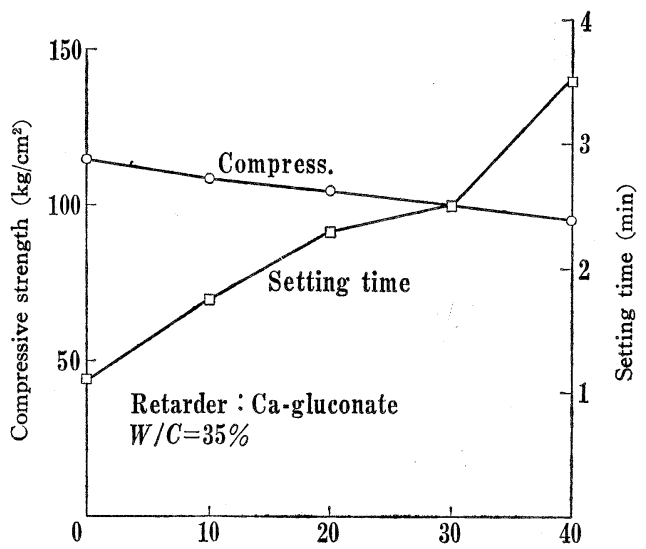

Ratio of portland cement to aluminous cement. (g)

Fig. 2. Hydraulic properties of blended mixtures as functions of the amount of portland cement added.

つぎに 3.2 に述べた最高強度が期待できる配合比に 基づいて，ポルトランド・セメントを添加した.すなわ ち,

(1) A.C. $=100 \mathrm{~g}$

(2) D.P. $=25 \mathrm{~g}$

（3）グルコン酸カルシウム $=1.25 \mathrm{~g}$

または, Ca.2 K.G. $=1.25 \mathrm{~g}$

(4) P.C. $=0,10,20,30,40 \mathrm{~g}$ 添加

（5） 水セメント比 $=35 \%$

上記の配合比にしてポルトランド・セメントの添加量 に対する凝結時間，および 30 分後の圧縮強度を測定し た. 実験結果を図-2（イオン封鎖剂としてグルコン酸カ ルシウムを用いた場合）と図-3（同様に 2 ケトグルコン 酸カルシウムを用いた場合）に示した.

この実験結果より，A.C.一石灰類一イオン封鎖剂系 にさらにポルトランド・セメントを添加すれば，その添 加量が増加するにしたがって, 30 分後の圧縮強度は多 少低下寸るが凝結時間はわずかながら伸びることが示さ れる. またアルミナ・セメントの価格がポルトランド・ セメントに比べてはるかに高いので, ポルトランド・セ メントを加えた方が経済的にもよいと考えられる.

\subsection{A.C.一石灰類一P.C. 系の凝結性}

この系において，石灰類として消石灰を用いた場合の 


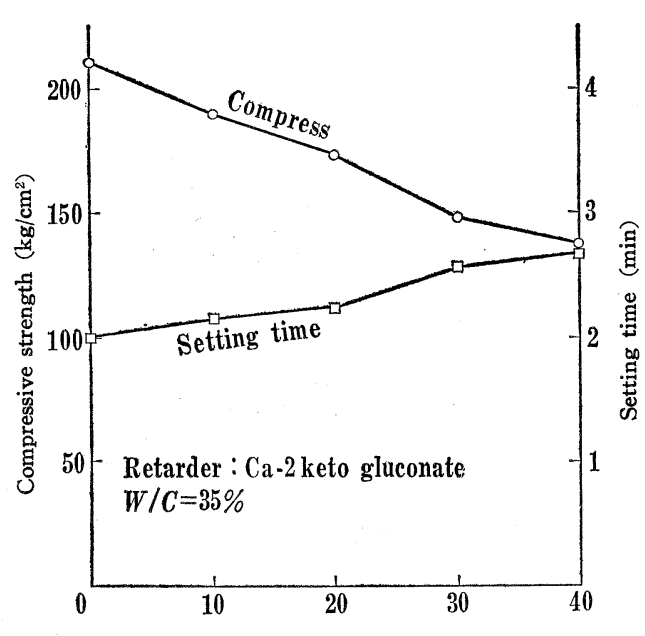

Ratio of portland cement to aluminous cement. (g)

Fig. 3. Hydraulic properties of blended mixtures as functions of the amount of portland cement added.

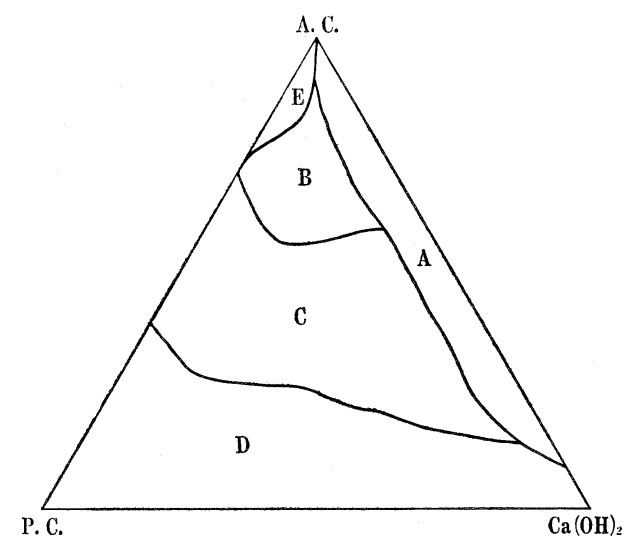

Fig. 4. Distribution of final setting time in the ternary system of aluminous cementportland cement- $\mathrm{Ca}(\mathrm{OH})_{2}$.

凝結時間を測定し三角図表に表した（図-4）.これより 凝結時間はつぎの 5 通りに分けることができた。すなお ち,

(A) 瞬結であったもの

(B) 凝結時間が 30 秒以内のもの

(C) 凝結時間が 60 秒以内のもの

(D) 凝結時間が 60 秒以上のもの

（E）凝結始発は速いが終結は遅れ硬化が遅れるもの 涵-4 に扔汀 A.C.-P.C. 系の 2 成分系では，ポルト ランド・セメント中に含まれるカルシウム化合物や遊離 石灰の影響により，急結性 (Quick setting) になる. 本 研究で扱った急硬性セメントは, 緒言にも述べたように 凝結始発まではセメント・ペーストの粘度をほとんど変 化させないで, 始発後終結に至る時間が極めて短かく, ほとんど始発と同時に硬化してしまうようなセメントを 目的としているのに対して, A.C.-P.C. 系の 2 成分系

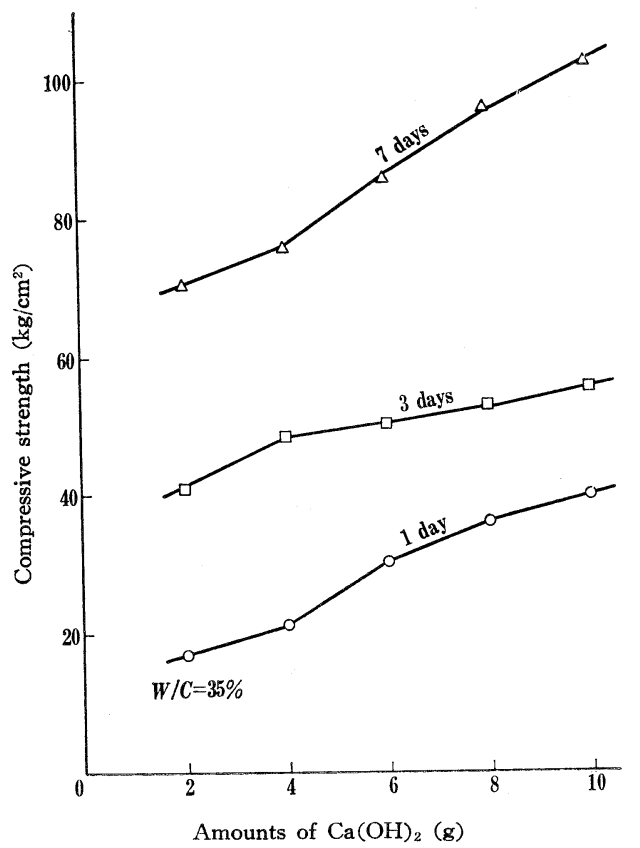

Fig. 5. Relations between compressive strength and amounts of $\mathrm{Ca}(\mathrm{OH})_{2}$ added to the mixtures with aging time as a parameter. Composition of specimen; aluminous cement 22, portland cement 78 , and milk casein 1 in gram.

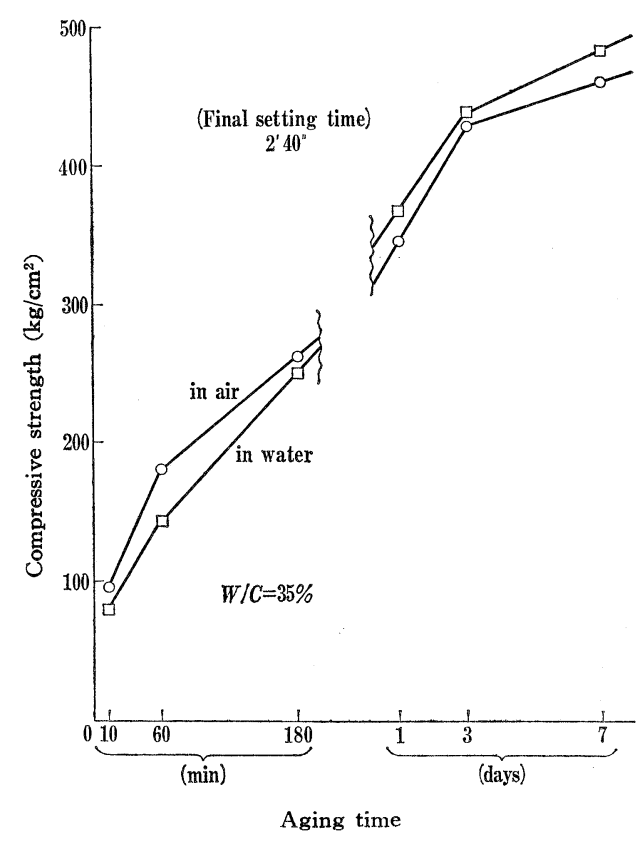

Fig. 6. Comparison of aging time vs compressive strength curves in air and in water. Composition of specimen; aluminous cement 100 , dolomite plaster 25 , and $\mathrm{Ca}-2$ keto gluconate 1.25 in gram. 


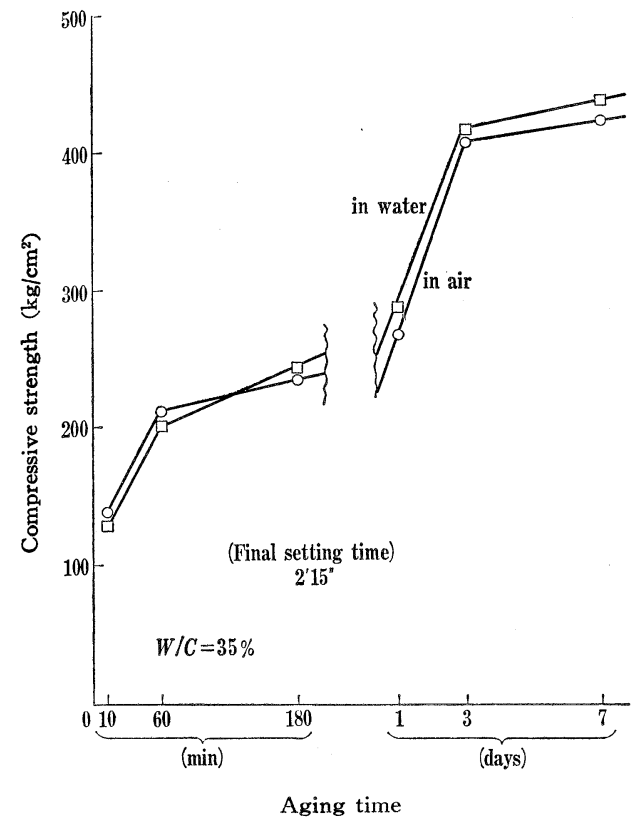

Fig. 7. Comparison of aging time vs compressive strength curves in air and in water. Composition of specimen; aluminous cement 100 , dolomite plaster 35 , and $\mathrm{Ca}-2$ keto gluconate 1.35 in gram.
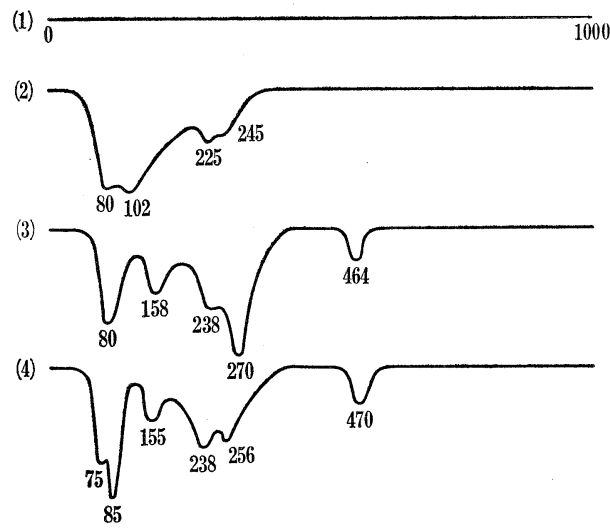

Fig. 8. Differential thermal analysis curves of aluminous cement No. 1 and the 7 days hydration products of rapid hardening cement. Heating up rate, $v=10 \sim 12$ $\left({ }^{\circ} \mathrm{C} / \mathrm{min}\right)$.

の場合では凝結の始発は速いが終結は遅れる。このため この 2 成分系は, 本研究の主:たる対象である 10 秒 数 分程度で凝結, 硬化するセメントとした場合, 短期強度 の発生は望めない. 前述の目的を達し得る急硬性(Quick hardening）とはならないため，使用しがたい。

\section{5 急硬性セメントの空中および水中強度}

実験室的に試作した急硬性セメントをいろいろな角度 から調べるために, 消石灰添加量と $1,3,7$ 日材令の圧 縮強度との関係を求めた．これを図 -5 に示す。またい

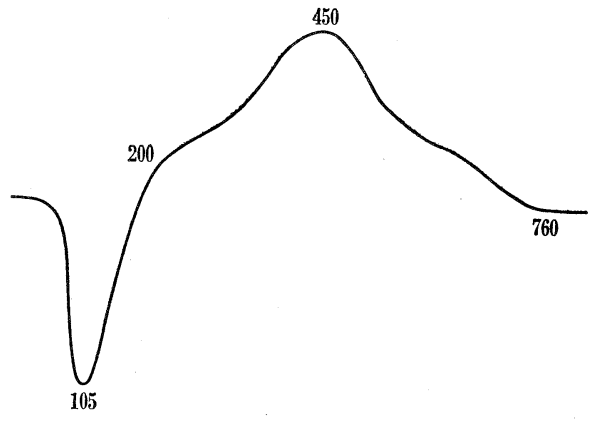

Fig. 9. Differential thermal analysis curve of $\mathrm{Ca}-2$ keto gluconate containing $\alpha-\mathrm{Al}_{2} \mathrm{O}_{3}$ in $80 \%$ (wt). Heating up rate, $v=10 \sim 12\left({ }^{\circ} \mathrm{C} / \mathrm{min}\right)$.

ろいろな配合比にして, 空中および水中強度の比較した 実験結果を図 -6, , 図-7 に示す。

\subsection{D.T.A. による解析}

本研究で扱った種々の急硬性セメントをつぎのような 順序で D.T.A. で解析した.

(1) A.C. 単独未水和試料の D.T.A.

(2) A.C. 単独水和, 材令 7 日試料の D.T.A.

(3) A.C. $+\mathrm{Ca}(\mathrm{OH})_{2}$ の水和, 材令 7 日試料の D.T. A.

(4) A.C. $+\mathrm{Ca}(\mathrm{OH})_{2}+\mathrm{Ca} \cdot 2$ K.G. の水和, 材令 7 日試料の D.T.A.

これらの試料はいずれも 3.2 に述べた配合比によって 調整した. その結果を図-8 に示した.

一方イオン封鎖剤として用いた 2 ケトグルコン酸カル シウムを $\propto$-アルミナと混合したものの D.T.A. 曲線を 図-9 に示す. 示差熱分析は何れも加熱速度 $v=10 \sim 12$ ${ }^{\circ} \mathrm{C} / \min$ で行なった.

\section{4. 考察}

1）本実験で用いたアルミナ・セメントの主な鉱物成 分は, X線回折により同定した結果, $\mathrm{CaO} \cdot \mathrm{Al}_{2} \mathrm{O}_{3}$ と 12 $\mathrm{CaO} \cdot 7 \mathrm{Al}_{2} \mathrm{O}_{3}$ であった. アルミナ・セメントの水和機 構についてはすでに多くの論文が報告されている.これ について小出”はつぎのように述べている.すなわち， アルミナ・セメントの鉱物成分である $\mathrm{CaO} \cdot \mathrm{Al}_{2} \mathrm{O}_{3}, 12$ $\mathrm{CaO} \cdot 7 \mathrm{Al}_{2} \mathrm{O}_{3}{ }^{8) \sim 10)}, \mathrm{CaO} \cdot 2 \mathrm{Al}_{2} \mathrm{O}_{3}{ }^{11)}$ などは，水和の過程 で $\mathrm{CaO} \cdot \mathrm{Al}_{2} \mathrm{O}_{3} \cdot 10 \mathrm{H}_{2} \mathrm{O}^{12)}, 2 \mathrm{CaO} \cdot \mathrm{Al}_{2} \mathrm{O}_{3} \cdot 8 \mathrm{H}_{2} \mathrm{O}^{13), 14)}$ お よび $\mathrm{Al}(\mathrm{OH})_{3}$ を生成し, さらに水和が進むと $\mathrm{Al}(\mathrm{OH})_{3}$ と $3 \mathrm{CaO} \cdot \mathrm{Al}_{2} \mathrm{O}_{3} \cdot 6 \mathrm{H}_{2} \mathrm{O}^{14), 15)}$ になると述べている.

本報告の場合にはアルミナ・セメントに石灰類を加え ているために，水和初期に認められる $\mathrm{Al}^{3+}$ と $\mathrm{Ca}(\mathrm{OH})_{2}$ との反応がきわめて急速に起り, 最終的には $3 \mathrm{CaO}$. $\mathrm{Al}_{2} \mathrm{O}_{3} \cdot 6 \mathrm{H}_{2} \mathrm{O}$ になるものと考えられる. したがって, 添加された $\mathrm{Ca}(\mathrm{OH})_{2}$ と $\mathrm{Al}^{3+}$ との反応を抑制するた めに, $\mathrm{Ca}^{2+}$ を封鎖する添加剂が必要になる.すなわち $\mathrm{Ca}^{2+}$ をアルカリ性の条件下でイオン封鎖するような化 
合物を添加すれば，凝結を遅緩させることが可能であ $\Xi^{16)}$. この種の添加剤は安定な錯塩をつくって $\mathrm{Ca}^{2+}$ を 封鎖してしまらと考えられるからである.

凝結遅緩効果に対しては, 全 $\mathrm{Ca}$ の量よりも, 溶存す る $\mathrm{Ca}^{2+}$ の量の方が重要な因子である。また $\mathrm{Ca}(\mathrm{OH})_{2}$ の飽和溶液では $\mathrm{pH}=12.6$ 程度であり, この急硬性セ メントの溶液でも $\mathrm{pH}=12.8$ 程度である。凝結遅緩剤 はこのような強アルカリ性の条件下で $\mathrm{Ca}(\mathrm{OH})_{2}$ と反応 して, $\mathrm{Ca}^{2+}$ を封鎖し錯塩を生成するものでなければな らない。たとえば, 凝結遅緩剤として表-2 に示した $\left(\mathrm{NH}_{4}\right)_{2} \mathrm{C}_{2} \mathrm{O}_{4} \cdot \mathrm{H}_{2} \mathrm{O}$ を用いた場合には, その化学反応式 は,

$$
\begin{aligned}
& \mathrm{Ca}(\mathrm{OH})_{2}+\left(\mathrm{NH}_{4}\right)_{2} \mathrm{C}_{2} \mathrm{O}_{4} \rightarrow \mathrm{CaC}_{2} \mathrm{O}_{4}+2 \mathrm{NH}_{4} \mathrm{OH} \\
& \text { (白色沈殿) }
\end{aligned}
$$

このような場合には凝結遅緩効果はない。すなわち， $\mathrm{Ca}(\mathrm{OH})_{2}$ が㠜結遅緩剂と反応するとき, 上に示した反 応式は $\mathrm{Ca}^{2+}+\mathrm{C}_{2} \mathrm{O}_{4}{ }^{2-} \rightarrow \mathrm{CaC}_{2} \mathrm{O}_{4}$ と考えられる.このよ らに単なるイオン反応である場合は凝結遅緩効果はな く，まったく逆に促進剂として作用する場合もあり得 る. 溶存する $\mathrm{Ca}^{2+}$ を減少させるか, または $\mathrm{Ca}^{2+}$ の活 動を抑制するような添加物を加えることによって, 試作 セメントの凝結が遅緩すると考えられる。

本研究で見られた凝結遅緩の機構として, 水和反応時 に Ca 錯塩が生成する過程が重要と思われる.

$$
\mathrm{Ca}(\mathrm{OH})_{2} \text { +凝結遅緩剤 } \underset{\text { アルカリ性の条件下 }}{\longrightarrow} \mathrm{Ca} \text { 錯体 }
$$

この過程に関する詳細はまだ明らかでない。たとえば E.D.T.A. は $\mathrm{Ca}^{2+}$ などアルカリ土類金属と安定な錯塩 を生成する. E.D.T.A. は $\mathrm{Ca}^{2+}$ と結合して配位数 6 の 安定な $\mathrm{Ca}$ 錯体を作る。

またグルコン酸も $\mathrm{Ca}^{2+}$ やその他の金属イオンを封鎖 すること，すなわち安定なキレート化合物を作ることも 知られている ${ }^{17)}$. しかしこれら Ca 錯塩の生成過程に現 われる中間化合物の形, 安定度, 逐次反応の起り方, 錯 体の構造式や配位数などはきわめて複雑で, まだ明らか でない.著者らも研究中であるがまだ結論を得ていな い.

2) 個々の凝結遅緩剤について調い゙た 結果（表-2 参 照)，もっとも効果のすぐれているのは 2 ケトグルコン 酸カルシウムであり，これはすぐれたイオン封鎖剤の一 つである.この原因は，第1に2 ケトグルコン酸カルシ りムが強アルカリ性の条件下で $\mathrm{Ca}^{2+}$ 封鎖するためと 考它られる.第 2 に，このイオン封鎖剤が，硬化後その 分子の一部を $\mathrm{CO}_{2}$ と $\mathrm{H}_{2} \mathrm{O}$ とに分解し, $\mathrm{Ca}^{2+}$ 封鎖の能 力を失うので, 試作セメントに添加する, しないにかか わらず水和物は同じであり，したがって強度が悪影響を 受けないためと考えられる.

著者らがこのように推論した 理由は以下のようであ る.たとえば， 2 ケトグルコン酸カルシウムをポルトラ
ンド・セメントに添加した場合，短期強度は弱いが，長 期強度には悪影響がないことが報告されている ${ }^{18)}$. 本実 験の場合でも，2 ケトグルコン酸カルシウムの無添加の 時と添加した時とを比較すれば,添加量が 0.05 ～ $0.30 \%$ と増加するにつれて， 3,7 日後の曲げ強度および圧縮強 度は著しく低下する.しかし 28 日後の強度は無添加の 時と比較してほぼ同じである.このように 28 日強度が 低下しないのは，2 ケトグルコン酸カルシウムがアルカ リ性の条件下で $\mathrm{Ca}^{2+}$ を封鎖する性質があるけれども， 水溶液中で徐々に $\mathrm{CO}_{2}$ と $\mathrm{H}_{2} \mathrm{O}$ とを放出しながら分解 して, $\mathrm{Ca}^{2+}$ 封鎖能力を失ない, 再び水和反応を進行さ せるためと考えられる。

また E.D.T.A. は 2 ケトグルコン酸カルシウムより 効果が少ない.この理由には, 第 1 に $\mathrm{pH}=10$ 程度でイ オン封鎖能力は大であるが，この試作セメントのように 強アルカリ性の条件下では効果が少ないこと, 第 2 にこ のセメントに石灰類として用いたドロマイト・プラスタ - $\left(\mathrm{Ca}(\mathrm{OH})_{2}\right.$ と $\mathrm{Mg}(\mathrm{OH})_{2}$ とが主成分) が E.D.T.A. と反応して錯塩を生成する場合, $\mathrm{Ca}$ 錯塩より $\mathrm{Mg}$ 錯塩 が安定性からいって生成しやすく，このため $\mathrm{Ca}$ 錯塩が できにくいことがあげられる ${ }^{19) ~ 21) . ~}$

またグルコン酸カルシウムの場合も E.D.T.A.の場合 と同じょうに, Ca 錯塩と $\mathrm{Mg}$ 錯塩との安定度の差に 原因して， $\mathrm{Ca}$ 錯塩が $\mathrm{Mg}$ 錯塩に比べてできにくいた め, 2 ケトグルコン酸カルシウムより効果が小さいと考 えられる。

前にも述べたように，2 ケトグルコン酸カルシウムで は非常に著しい遅緩効果が得られたけれども，これに対 して 5 ケトグルコン酸カルシウムはまったく効果がな い.これは 2 ケトグルコン酸カルシウムと 5 ケトグルコ ン酸カルシウムとが構造上類似しておりながら(この 2 つの物質の間では, $-\mathrm{COOH}$ 基と $>\mathrm{C}=\mathrm{O}$ 基との関係 位置のみが 異なる), $\mathrm{Ca}$ 錯塩を生成する 過程はまった く異なっているからと考えられる.これについては，有 機錯体に関する研究をしないとわからないが，今後研究 の対象として目を向けることにしてここではふれない。

3）アルミナ・セメントに石灰類を $1 \%$ 添加しただけ でも急結になるが，強度発生の点から石灰の $20 \%$ 以上 の添加が必要になる．また凝結の促進にだけでなく，短 期強度発生にも大きな役目を果す.これは実験例（図-1 参照）からも理解できる.すなわち、アルミナ・セメン トと消石灭は重量比で $5: 1$, ドロマイト・プラスター は $4: 1$, の割合が高強度の期待できる配合比となる。

図-8の D.T.A. 曲線において (2) と（3）とを比較 すると、アルミナ・セメントの単独水和物の D.T.A. と A.C. $-\mathrm{Ca}(\mathrm{OH})_{2}$ 系の水和物の D.T.A. とはまったく異 なっている.これは急硬性セメントに用いる石灰類がア ルミナ・セメントと化学的に反応することを示してい 
る.ただし（3）の D.T.A. で $464^{\circ} \mathrm{C}$ の吸熱ピークは 末反応の $\mathrm{Ca}(\mathrm{OH})_{2}$ と考えられる。

つぎに（3）と（4）とを比較すると,80，158，238，464 ${ }^{\circ} \mathrm{C}$ にそれぞれたがいに対応するピークが認められた. これは 4.の 2) にも述べたように,イオン封鎖剤とし ての 2 ケトグルコン酸カルシウムが, 硬化後その分子の 一部を $\mathrm{CO}_{2}$ と $\mathrm{H}_{2} \mathrm{O}$ とに分解して $\mathrm{Ca}^{2+}$ 封鎖能力を失 うため，これの添加の有無にかかわらず生成する水和物 は同じであるためと考えられる。

各温度での吸熱ピークはどのような意味をもつか. 最 初の脱水から始まり，末反応の $\mathrm{Ca}(\mathrm{OH})_{2}$ の吸熱ピーク に至るまでの複雑な過程は今のところ解明していない。 前に述べた $\mathrm{Ca}$ 錯塩の生成過程と共に実験中であるが， まだ結論を得ていない.

\section{5. 総括}

以上のことを要約すればつぎのよらになる.

1) アルミナ・セメントに石灰類を加えると瞬結性に なり，セメントとして使用しがたい.しかしこれに凝結 遅緩剤として，強アルカリ性の条件下で $\mathrm{Ca}^{2+}$ を封鎖す るものを添加すれば，凝結は遅緩する．

2)この遅緩剂を検索した結果，2ケトグルコン酸カ ルシウムが著しい効果を示すことが判明した。また著者 らは実験室的に試作した混合セメントの高強度が期待で きる配合割合を明らかにした.すなわち，アルミナ・セ メント $100 \mathrm{~g}$, 石扊類として消石灰 $20 \mathrm{~g}$ またはドロマイ ト・プラスター $25 \mathrm{~g}, \mathrm{Ca}^{2+}$ 封鎖剤を $1 \%$ (アルミナ・ セメント十石灰類の 1\%)，そして水セメント比を $35 \%$ で水和させた。

3)この試作セメントは吹き付け工事や緊急を要する 土木工事用などに利用できる。しかもこれは数十秒〜数 分で凝結, 硬化する.

4）アルミナ・セメント一石灰類系の他に，ポルトラ ンド・セメントを添加しても凝結はわずかながら遅緩す る.これはポルトランド・セメント中の $\mathrm{CaSO}_{4} \cdot 2 \mathrm{H}_{2} \mathrm{O}$ の影響によるものである.

5）石灰類はアルミナ・セメントと反応し，凝結促進 材として働くばかりでなく短期強度発生に役立つ。

\section{6.むすび}

本研究では, 3.3 に述べた $\mathrm{CaSO}_{4} \cdot 2 \mathrm{H}_{2} \mathrm{O}$ による影響 に関連すると思わ玌る $\mathrm{Ca}(\mathrm{OH})_{2}-\mathrm{CaSO}_{4} \cdot 2 \mathrm{H}_{2} \mathrm{O}-\mathrm{Ca}^{2+}$ 卦
鎖剂系の液相組成の解析 ${ }^{22)}$ ，および Ca 錯塩の生成過程 の解明はまだ充分なされていない.

最近アメリカにおいても，詳細は不明だが，Fast Fix Cement や Jet Set などの商品名で, この目的のセメ ントが開発されている。本報告においてもさらに経済的 な観点からは，アルミナ・セメントの価格がポルトラン ド・セメントに比べてかなり高価なため，この急硬性セ メントの原料としてアルミナ・セメントを使用しない で，他の原料を用いてしかも同様な効果を得るのが望ま しい.またこの試作セメントにさらに接着性を与える方 法がまだ明らかでない，接着力がかなり強ければまた別 の面での利用価值が生ずると思う。これも今後の問題と なろう。

\section{文献}

1）中原万次郎, 笠井順一, 露木尚光, 町長 治, 佐々木 隆, 案協セメント部会講演要旨集 (1966).

2) 笠井順一, 露木尚光, 佐々木 隆, 日大生産工第 1 回学 術講演会要旨集 (1967).

3）中原万次郎, 笠井順一, 露木尚光, 佐々木 隆, 日本化 学会第 20 年会講演要旨集 (1967).

4）露木尚光, 笠井順一, 日大生産工第 2 回学術講演会要旨 集 (1967).

5) C.L. Mehltretter, B.H. Alexander and C.E. Rist, Ind. Eng. Chem. 45, 2782 (1953).

6) 露木尚光, 笠井順一, 日本化学会第 21 年会講演要旨集 (1968).

7）小出重明, 弿協 69 [2] 15-23 (1961).

8) H.F.W. P Taylor, The Chem. of Cements, Vol. 2 Academic ress (London and New York) 12-4 (1964).

9) T.W. Parker, Proc. Symp. Chem. Cement, 485-99 (1952).

10) W. Eitel and W. Büssem, Z. Krist. A 95 175-88 (1936).

11) C. Caria and A. Bürdese, Ricerca Sci. 21, 1613-22 (1951).

12) G. Assarsson, Sveriges Geol. Undersökn. [C] 27, [379] 22 (1933).

13）竹本国博，セメント技術年報 7, 19-27 (1953).

14) P.P. Budnikov and I.V. Kravchenko, Kolloid Zhur. 21, 9-17 (1959).

15) S.J. Schneider, J. Am. Ceram. Soc. 42, 184-93(1959).

16）笠井順一，窯協 71 [2] 27-31 (1963).

17) Encyclopedia of Chem. Technology.

18）中原万次郎, 笠井順一, 学振 76 委員会資料 (1965).

19）中原万次郎，笠井順一，宮川継男，青木繁樹，国友義和， 門倉利夫, 石膏と石灰 No. 41, 25-32 (1959).

20）笠井順一，酒井誠一，中原万次郎，石高と石灰 No. 65, 143-7 (1963).

21）田中, 杉共訳, 錯形成反応 p. 267-351 (産業図書).

22）露木尚光, 笠井順一, 未発表.

(4/3/1969 受付) 